\title{
Sosialisasi Manajemen Strategi Pemasaran Di UMKM Kecamatan Cileungsi
}

\author{
Ana Wijandari ${ }^{1}$, Neng Sumilah ${ }^{2}$ \\ ${ }^{1}$ STEBIS Bina Mandiri, Bogor, Indonesia \\ ${ }^{2}$ STEBIS Bina Mandiri, Bogor, Indonesia \\ ana.wijandari@gmail.com
}

\begin{abstract}
Abstrak: Program pengabdian ini bertujuan agar UMKM memahami strategi-strategi bagaimana mengembangkan usaha dengan memahami bauran atau marketing mix yang terdiri 4 P (Product/Produk, Price/Harga, Place/Tempat, Promotion/Promosi).Tujuan pengabdian ini adalah memberikan pengetahuan kepada masyarakat khususnya UMKM berupa sosialisasi strategi yang dapat dilakukan untuk bersaing dalam pasar persaingan produk. Metode yang digunakan dalam kegitatan ini dengan cara sosialisasi kepada UMKM tentang strategi dalam memenangkan pasar persaingan produk. Kegiatan ini dilaksanakan di Desa Cileungsi Kabupaten Bogor. Peserta kegiatan ini adalah para UMKM dengan jumlah sekitar 20 UMKM. Hasil yang didapatkan dalam program pendampingan ini adalah para UMKM mampu menyusun strategi atau rencana pemasaran dengan baik dan benar.
\end{abstract}

Kata Kunci: Pemasaran UMKM, Strategi Manajemen, Strategi Pemasaran, Marketing UMKM

Abstract: This service program aims to make the Micro, Small Medium Enterprises (MSMEs) to fully understand the strategies on how to develop businesses by understanding the Marketing Mix-also known as the 4 Ps (Product, Price, Place, and Promotion). The purpose of this service is to provide knowledge to the community, especially MSMEs in the form of socializing strategies which is possible to apply in order to be able to compete in the product market competition. The method used in this activity is by socializing to MSMEs about strategies to win product market competition. This activity was carried out in Cileungsi Village, Bogor Regency. The participants of this activity are MSMEs with a total number 20 MSMEs. The Result obtained from this mentoring program is that the MSMEs are able to develop strategies or marketing plans properly and correctly.

Keywords: MSMEs Marketing, Management Strategy, Marketing Strategy, MSMEs Marketing

\section{Pendahuluan}

Manajemen strategi pemasaran merupakan perencanaan strategi yang berorientasi pada jangkauan masa depan yang jauh (disebut visi), dan ditetapkan sebagai keputusan pimpinan tertinggi keputusan yang bersifat mendasar dan prinsipil, agar memungkinkan organisasi berinteraksi secara efektif (diucap misi), dalam usaha menghasilkan sesuatu (perencanaan operasional untuk menghasilkan benda serta/ataupun jasa dan pelayanan) yang bermutu, dengan ditunjukan pada optimalisasi pencapaian tujuan (diucap tujuan strategis) dan berbagai sasaran organisasi. Begitu banyak pengertian manajemen strategi, namun pada dasarnya manajemen strategi merupakan suatu sistem yang sebagai satu kesatuan memiliki berbagai komponen yang saling berhubungan dan memengaruhi (Setiawan, 2018). Dalam strategi pemasaran diperlukan visi misi yang nantinya akan menjadi sebuah acuan tujuan yang baik dan mengarahkan para pelaku usaha untuk tetap berada pada jalur yang sesuai demi tercapainya tujuan. Konsep pemasaran menegaskan bahwa kesuksesan sebuah organisasi dalam mewujudkan tujuannya sangat dipengaruhi oleh kemampuannya dalam mengindetifikasi kebutuhan dan keinginan pelanggan sasarannya dan memberikan kepuasan yang diharapkan secara lebih efektif dan efisisen, serta menjaga loyalitas pelanggan. Kepuasan pelanggan yang menciptakan loyalitas merupakan faktor yang penting 
dalam kesuksesan perdagangan dan kemampuan pengusaha untuk bertahan (Farisi, 2021). Strategi ini adalah yang dilakukan untuk membangun hubungan baik dengan semua konsumen sehingga akan membentuk hubungan bisnis yang berkelanjutan, maka dalam hal ini dapat juga diterapkan pada UMKM yang memiliki beragam pelaku usaha dan produk.

Usaha Mikro Kecil dan Menengah (UMKM) berperan penting dalam pembangunan ekonomi nasional. Selain berperan dalam pertumbuhan ekonomi juga berperan dalam penyerapan tenaga kerja (Rahmadi et al., 2018). Dengan demikian, para pelaku usaha harus memiliki strategi yang mampu bersaing dengan produk lain dengan cara melakukan pemasaran secara online menggunakan media sosial sebagai media pemasaran yang efektif di masa pandemi sekarang ini. Tentu dibutuhkan inovasi dan kreativitas para pelaku usaha dalam mengenmbangkan usahanya, inovasi dan kreativitas ini dengan membuat media iklan berupa flyer/poster yang menarik. Desain media promosi haruslah dibuat dengan baik dan efektif untuk memudahkan para konsumen dalam mencerna media promosi tersebut.

Salah satu kelemahan pengusaha kita adalah dalam bidang strategi. Strategi merupakan alat yang sangat penting bagi kemajuan suatu perusahaan. Setiap perusahaan yang bersaing dalam suatu industri pasti mempunyai strategi bersaing. Dalam perubahan pola persaingan yang sangat ketat ini, strategi suatu perusahaan harus disesuaikan atau bahkan diubah untuk memperoleh peluang-peluang serta menghindari ancaman dari para pesaing (Kasmir, 2012). Rendahnya strategi yang dimiliki oleh para pelaku usaha menjadi hal yang buruk untuk kemajuan usaha yang digelutinya, dengan strategi pemasaran yang menggunakan media promosi baik online maupun offline (mouth to mouth) akan menjadi salah satu strategi yang bisa diandalkan oleh para pelaku usaha UMKM yang ada di wilayah nasional khususnya Cileungsi, Jawa Barat.

Guna para pelaku usaha UMKM dalam menghadapi tantangan pemasaran ini, sangatlah penting untuk mempersiapkan diri dengan perencanaan yang baik dan mengetahui strategi yang dapat dilakukan untuk memasarkan hasil usahanya. Karena dengan strategi yang tepat dan merupakan cara untuk mengenalkan produk kepada masyarakat umum untuk mendapatkan hasil yang maksimum.

\section{Metode}

Kegiatan yang dilakukan adalah sosialisasi kepada para pelaku UMKM dalam menyusun rencana pemasaran yang baik dan efektif serta memberikan informasi mengenai bagaimana masarkan produk secara online maupun offline. Dengan harapan para pelaku UMKM mampu menghadapi tantangan dalam dunia bisnis dan mampu mempersiapkan strategi perencanaan yang matang dalam memasarkan produk yang dimiliki agar laba yang diperoleh meningkat walau dimasa pandemi. Juga, para pelaku usaha diberikan informasi pemasaran yang dilakukan secara online menggunakan aplikasi berbasis website yang telah dilakukan sosialisasi sebelumnya di UMKM Cimanggis agar masyarakat nantinya mampu mengembangkan bisnis jual beli online berbasis website (Haryadi et al., 2021). 
Kegiatan ini dilaksanakan di Cileungsi Kabupaten Bogor Provinsi Jawa Barat secara ceramah serta diskusi dengan para pelaku usaha. Kegiatan pengabdian kepada masyarakat dilaksanakan pada tanggal 10 Agustus 2020. Peserta kegiatan ini adalah para UMKM dengan jumlah 53 orang yang dibagi menjadi 2 termin/hari.

\section{Hasil dan Pembahasan}

Pelaksanaan kegiatan pengabdian kepada masyarakat ini secara umum sesuai dengan target tim pengabdian yang telah disusun dengan pelaksanaan kegiatan dilaksanakan selama dua hari karena dalam hal ini menginggat keterbatasan waktu yang dimiliki oleh peserta, sehingga pada akhirnya tim pengabdi bersepakat dengan peserta untuk melaksanakan kegiatan selama dua hari dengan tetap mematuhi protokol kesehatan.

Pengabdian kepada masyarakat ini mendapatkan respon yang baik dari para pelaku usaha UMKM yang ada di daerah Cileungsi yang dapat dilihat dari antusiasme masyarakat sejak pertama kali program ini dibicarakan dengan ketua UMKM Cileungsi yang diteruskan dengan para pelaku usaha, antusiasme sangat terasa, koordinasi telah dilakukan secara terus menerus untuk mendapatkan waktu yang pas kapan pelaksanaan kegiatan ini akan dimulai. Walaupun sinkronisasi waktu antara pelaku usaha dengan tim pengabdi, akhirnya didapatkan waktu yang disepakati.

Dari beberapa kesan dan masukan dari peserta, umumnya mereka merasa sangat antusias dalam mengikuti kegiatan ini, metode yang digunakan dalam pelatihan ini tidak memforsir mereka untuk langsung bisa menguasai materi pelatihan, tetapi sedikit demi sedikit asalkan yang penting paham, sehingga di awal terkesan waktu yang digunakan untuk pemahaman relatif lama. Akan tetapi ternyata waktu untuk memahami yang relatif lama inilah yang menjadi keunggulan sosialisasi ini, karena hampir semua peserta menjadi benar-benar paham.

Hasil dari pelatihan ini pun melebihi perkiraan dari tim pengabdi, dikarenakan antusiasme peserta yang begitu besar. Walaupun dari segi isi dan materi mungkin masih banyak kekurangan, tetapi pada dasarnya peserta sudah mampu memahami inti dan tujuan dari sosialisasi ini.

Inti dari pengabdian kepada masyarakat ini untuk mendapatkan hasil yang baik dan maksimum dalam informasi strategi yang dilakukan oleh para pelaku usaha yang tergabung di UMKM Cileungsi Kabupaten Bogor, Jawa Barat.

\section{Kesimpulan}

Berdasarkan kegiatan yang telah dilaksanakan oleh Tim pengabdian kepada masyarakat di Kecamatan Cileungsi Kabupaten Bogor, disimpulkan peserta memahami bahwa pemasaran merupakan proses penciptaan dan penyampaian barang dan jasa yang diinginkan kepada pelanggan dan meliputi kegiatan yang berkatian dengan memenangkan dan mempertahankan pelanggan agar setia. Salah satu dari langkah pertama dalam menyusun rencana pemasaran merupakan proses penciptaan dan penyampaian barang dan jasa yang diinginkan kepada 
pelanggan dan meliputi kegiatan yang berkatian dengan memenangkan dan mempertahankan pelanggan agar setia. Salah satu dari langkah pertama dalam menyusun rencana pemasaran adalah mengidentifikasi pasar sasaran. Pasar sasaran atau target market yang dimaksud adalah kelompok pelanggan tertentu yang terhadapnya perusahaan mengarahkan barang dan jasanya. Semakin banyak perusahaan mempelajari pasar lokalnya, pelanggannya, serta kebiasaan, semakin tepat perusahaan tersebut memfokuskan usaha pemasarannya pada kelompok calon pelanggan yang telah ada yang kemungkinan besar akan membeli produk dan jasanya. Unsur utama dalam strategi pemasaran adalah 4P yaitu product, place, price, dan promotion. Keempat faktor ini saling memperkuat dan jika terkoordinasi dengan baik akan meningkatkan daya tarik penjualan suatu produk dan jasa. Dengan diberikannya keseluruhan sosialisasi tersebut, pelaku usaha UMKM di Kecamatan Cileungsi Kabupaten Bogor diharapkan dapat memaksimalkan kegiatan usahanya agar dapat berkembang lebih baik lagi di masa mendatang.

\section{Ucapan Terima Kasih}

Melalui laporan pengabdian ini kami mengucapkan banyak terimakasih atas segala bantuan dan kesempatan kepada:

1. Ketua STEBIS Bina Mandiri Cileungsi

2. Ketua Prodi Akuntansi

3. Mahasiswa Prodi Akuntansi

4. Semua pihak yeng telah memberikan bantuan dan sumbangan pemikiran hingga pengabdian ini dapat diselesaikan.

\section{Referensi}

Farisi, M. S. Al. (2021). PENGARUH BAURAN RITELTERHADAP LOYALITAS MELALUI KEPUASAN PELANGGAN PADA PAMELLA SWALAYAN YOGYAKARTA. Jurnal Manajemen Bisnis Dan Keuangan, 1(1). Https://Doi.Org/10.51805/Jmbk.V1i1.2, 1(1), 1-14. https://jurnal.binamandiri.ac.id/index.php/jmbk/article/view/2/3

Haryadi, R. N., Rojali, A., Fauzan, M., \& Beli, J. (2021). Sosialisasi Penggunaan Online Shop berbasis Website di UMKM CImanggis. 1(1), 10-16.

Kasmir. (2012). Kewirausahaan. PT Raja Grafindo Persada, cetak ke 7, 279.

Rahmadi, R., Soolany, C., \& Pratama, A. R. (2018). Penerapan Manajemen Strategi Pemasaran untuk Meningkatkan Daya Jual Produk UMKM Gula Merah di Kabupaten Cilacap. Jurnal Rekayasa Teknologi Industri Hijau, 3(2), 1-6.

Setiawan, R. Y. (2018). Manajemen Strategi Pemasaran KJKS BMT Mandiri Getasan. 